\title{
PROFESSIONAL LEADERSHIP IN LOCAL GOVERNMENT
}

By: Ruth Hoogland DeHoog and Gordon P. Whitaker

DeHoog, Ruth Hoogland and Gordon P. Whitaker. "Professional Leadership in Local Government," International Journal of Public Administration 16 (1993): 2023-2049.

Made available courtesy of Taylor and Francis: http://www.tandf.co.uk/journals/titles/01900692.asp

***Note: Figures may be missing from this format of the document

\begin{abstract}
:
Local public service professionals are experts who temper their use of expertise with public service ethics. Public service ethics differ from the ethical codes of most professions in that they stress external accountability. Ethical codes of private sector professions create a sense of responsibility to the profession and help undergird professional autonomy. Public service ethics emphasize public responsibility and help create public accountability. City and county managers show how public service ethics can help make experts accountable to the public.
\end{abstract}

\section{Article:}

\section{INTRODUCTION}

"Professionalism in local government is essential!" "Professionalism in local government is impossible!" Can these two competing views of local government professionalism be reconciled? We believe that they can. In this paper, we argue that professional public servants resemble other professionals, in that they are experts who also share a set of defining values about their work. Public service professionals differ from private sector professionals in terms of their autonomy and accountability, however. Our purpose in this paper is to demonstrate how professionalism in local government helps make public service experts accountable to the public, rather than to their colleages as in private sector professions.

Our contention is that the chief difference between public service professionals and their private sector counterparts lies in their systems of accountability. Law, medicine, and the other professions which developed in the private sector place a high value on professional autonomy. They stress the accountability of members of the profession to each other. These professions have developed both value systems and organizational arrangements which support accountability within the profession and insulate against accountability to those outside the profession. Under our system of government, public service professions do not share that emphasis on professional autonomy.

Uncertainty about the place of professional leadership in our local governments results from the tension between two conflicting values in American political thought. On the one hand, many observers believe that effective and efficient government operations depend on leadership by experts. Modern public services must be directed and delivered by professionals qualified by virtue of their knowledge and skills, selected on the basis of their education and experience, and trained to make decisions on behalf of the public interest. On the other hand, this country shows strong commitment to the idea that democratic, accountable government depends on the popular election of government leaders. Representation is achieved and legitimacy is sustained through officials' election by the people being governed.

We believe that both expertise and democratic accountability are essential to the kind of government we seek. The requirements of democratic accountability impose special obligations on experts in public service. Explicit recognition of responsibility to the public distinguishes public service professions from the professions which developed in the private sector. 
The tension between the need for expertise and the need for popular accountability is particularly strong in local government. Local governments provide many complex goods and services, each with its own production technologies, financing requirements, and staffing needs. Experts are tempted to concentrate on the technical aspects of their work, develop their own fiefdoms, and ignore input from clients, elected officials, and general administrators. At the same time, however, local politics in many places has become more heterogeneous and citizens more involved in administrative decisions, about such issues as low-income housing, road planning, and environmental management. In many local governments, democratic accountability occurs not only through the popular election of officials representing diverse interests, but also through the participation of many other citizens on boards and commissions, at hearings, and in direct encounters with public officials. In their increased involvement in local decisions, citizens and community organizations have frequently challenged the positions of public service experts.

Our primary focus is on city and county managers. While some of the same knowledge, skills, and values affect the work of department heads (and mayoral associates in the mayoral forms of government), our discussion specifically concerns professional city and county managers. Through their training in Master of Public Administration programs, their professional development in such organizations as the International City/County Management Association (ICMA), and their daily challenges, managers have dealt quite consciously with the tension between expertise and popular accountability as bases for public leadership. As a result, these managers today exemplify in their work the professional values which reconcile that tension. Their work embodies both expertise and the public service ethics which we identify as the distinguishing characteristic of public service professionalism.

Professional city and county managers inform their use of expertise with three specific public service values. Those values, we argue, provide a particular emphasis for local government professionalism which distinguishes it from private sector professions.

The three values are these: 1) respect for other professions' expertise, as well as one's own, 2) acceptance of the legitimacy of politics and the authority of elected officials, and 3) adoption of an ethic of responsibility to the public at large. In our view, professional public management in the United States requires the tempering of expertise with these three key values.

\section{THE PROFESSIONALIZATION OF LOCAL PUBLIC MANAGEMENT}

Members of private sector professions typically set their own norms of practice and hold themselves accountable for breaches of those norms. They also frequently control access to the practice of their profession through credentialing or licensing. Consequently, professions are often seen as self-protective, restricting access to practice in order to raise the status and incomes of their members. Public service professionals do not have professional autonomy, however, and do not typically control access to the profession.(1)

If autonomy is an essential feature of any profession, we neither have nor want professional public servants in the United States. Autonomy is not the key feature of professionalism, however. Expertise is the essential characteristic of any profession.

One of the most basic objections to viewing government employees as professionals is the belief that no specialized knowledge of public administration really exists. "Beginning as early as the 1930s, scholars, both in and outside of the field, have seriously questioned the theories, facts, and principles that constitute the corpus of knowledge in public administration.(2) No one can be educated and certified as an expert if there is no widely accepted body of knowledge to be learned.

In our view, expertise is the defining feature of any profession: knowledge and skill must be developed and transmitted from one generation of experts to the next. Expertise is the core of professionalism. We argue that there are a body of knowledge and a set of values which serve as the basis for local public management. In the next section, we discuss the development of expertise in local government management. 
Other characteristics are important, too, however. Typically, professional standing (usually based on expertise) confers authority to make decisions within the area of professional competence. We find that many local public managers -- the ones we would characterize as professional - share professional standing and competence similar to that of professions which developed in the private sector.

But what of the values and ethics of professions? The structure and values of popular accountability in U.S. governments limit the exercise of professional authority, the scope of professional self-regulation, and professional control of access to practice in public administration. However, other professional values can and do play an important part in shaping behavior. We argue that three public-service values, in particular, help many city and county managers interpret and apply their professional expertise so that it supports democratic accountability. Rather than buttressing professional insularity, these values open the profession, stressing the interdependence of local government professionals, elected officials, and the community at large.

To be professional, a public manager must have both appropriate expertise and appropriate values shaping the use of that expertise in service to the public.

\section{Expertise in Local Government Management}

The need for expertise in local government arose along with the development of the technologies supporting modern urban life. Cities needed engineers to oversee water, sewer, and street systems. (Not surprisingly, many of the first city managers were engineers.) But the technical problems facing city administrators involved much more than physical infrastructure. Increasingly complicated finances for capital projects and operating expenses required more expertise in budgeting and financial management. An increasingly specialized work force and new legal strictures for public employment required more expertise in personnel administration. Public demands for land use controls and growth management, for safer buildings and better fire protection, for more responsive and equitable policing, and for public housing and a host of other social services have continued to develop throughout the twentieth century. An overriding concern for effectiveness and efficiency in government led the reformers who instituted the city manager form of government in the early years of this century to search for expert managers to head city administration.

More recently concern for equity and responsiveness of public policies and service delivery have broadened the range of expertise which councils have sought in their professional managers. Managers are now often expected to help balance and integrate the often competing demands of diverse constituents of the local government. As John Nalbandian puts it: "City management has become as concerned with the creation and nurturing of governmental processes as with the efficient and effective delivery of municipal services."(3)

Managers' formal education is both a source and a measure of their expertise. The content of formal education of managers has changed substantially over the years. In 1934, 77\% of the college- graduate managers responding to a nationwide survey had majored in engineering. By 1971 , only $33 \%$ of the college-graduate managers had their most advanced degree in engineering, while $12 \%$ were in public administration and $14 \%$ were in business administration. Liberal arts was the most common major for managers in 1971.(4) Another shift occurred during the 1970s. By 1984, 65\% of the college-graduate managers had their highest degrees in public administration (or planning), another $10 \%$ had their highest degree in business, and engineering degrees accounted for fewer than $2 \%$ of the managers' highest degrees. (5)

More of the managers had attended college and had earned advanced degrees by the 1980s also. In 1934, only $64 \%$ of the managers were college graduates and only a fifth of these had graduate degrees. By 1971, still only $69 \%$ of the managers were college grads, although nearly two fifths of these also held graduate degrees.(6) During the 1970s the level of formal education of managers increased markedly. By 1984, 88\% of the managers were college graduates and almost four fifths of these also held graduate degrees, mostly the Master of Public Administration (MPA) degree.(7) 
MPA education also became more standardized during this period. The National Association of Schools of Public Affairs and Administration (NASPAA) was established in the early 1970s. By the end of the decade, its member schools had adopted a set of Standards for Professional Masters Degrees in Public Affairs and Administration. In 1986, NASPAA was certified as the accrediting agency for professional masters programs in public affairs and administration. By 1990, nearly one hundred professional masters programs had been accredited by NASPAA, and many others followed the standards of NASPAA in developing their curricula in preparation for accreditation.

While no set curriculum is required for accreditation, NASPAA standards specify certain common curriculum components in which all MPA students are to be prepared, including: 1) the management of public organizations--human resources, budgeting and financial processes, and information, including computer literacy and applications; 2) the application of quantitative and qualitative techniques of analysis in decisionmaking and various stages of the policy process and program development; and 3) the understanding of the public policy and organizational environment--political, legal, economic, and social institutions and processes as well as organization and management concepts and behavior.

NASPAA curriculum standards reflect a growing consensus about what public managers need to know. While there is considerable diversity of opinion about specific theories, approaches, and techniques, city managers generally agree on the importance of most of the subjects in the NASPAA common curriculum.(8) Similarly, the NASPAA curriculum includes topics relating to the skills which managers reported as most important to them in their work. Not all managers believe their generalist academic training prepared them for their positions in local government, however. (See, for example,(9)) Recognizing the special requirements in city and county government, a joint task force of the ICMA and NASPAA produced a report entitled Guidelines on Local Government Management Education.(10) These guidelines go beyond NASPAA's common curriculum requirements to call for more specific preparation for city/county managers. Indeed, many MPA programs already offer concentrations in city, county, and/or urban management which embody these recommendations. Quite clearly there is a widely accepted body of knowledge that is particularly relevant to local managers and which provides a basis for their work.

Of course, not all expertise for city/county management can be learned in school. Continuing education programs and on-the-job apprenticeships have been an important part of many managers' professional preparation. And they will continue to be important, even for managers who complete the very best MPA programs, as new challenges arise, new knowledge is developed, and new techniques are devised. Indeed, more than $93 \%$ of managers reported in 1984 that they had participated in continuing education during the preceding two years. Most of them reported taking part in several different programs. (11)

In sum, there is a body of knowledge which is transmitted to aspiring practitioners and which informs their practice of local government management. In this regard, public service professionalism is like professionalism in the private sector.

\section{Access to Practice and Accountability}

Regardless of where local government managers obtain their expertise, however, access to practice as a city or county manager is controlled by the local governing boards composed of elected officials. No one becomes a city or county manager unless he or she is hired to serve in that position by a majority of the council or commission elected by the jurisdiction's citizens. And anyone may be hired -- not only those who have a MPA degree, have had prior management experience, or who are members of the ICMA.(12)

Whom do boards hire? A survey of managers newly hired in 1986 found that $55 \%$ of them came from other positions as chief administrator, while $45 \%$ were from another position.(13) Even if they do not hire someone who has already served as a manager, however, most councils appear to favor candidates who have education and experience in the field. Two-thirds of the newly hired managers had masters degrees in public administration and only $7 \%$ reported fewer than three years of experience in the field of city management. 
Three-fourths of the managers were hired from another municipality, 10\% from another type of public agency, and $5 \%$ from the private sector. Only $10 \%$ were promoted from within the same government. Most boards find the expertise they seek in a manager who has an MPA and substantial experience in city government.

The particular areas of expertise sought by each council depend, of course, on their perceptions of the needs of their jurisdictions. For example, some communities face problems of a stagnant local economy while others are confronted by booming growth. One board may thus seek a manager who is skilled in economic development, while another looks for an expert in growth management. Many communities now use executive search firms to recruit and screen manager applicants. As Ammons and Glass remark, "the perception that the executive function is immensely more complex than ever before is sufficient to propel the belief that the old ways of finding a manager may no longer be sufficient. "(14)

Finally, the council-manager form of government is designed to promote accountability and to ensure responsiveness to the elected council. Once hired, almost any city or county manager may be fired for any reason, at any time, by any majority of the elected board. The manager's professional training, affiliation, or expertise in local government offer little protection against termination.(15)(16)

City and county managers neither control access to practice nor provide the major accountability for the practice of city and county management. In this they differ from medicine, law, and other professions which developed in the private sector. This difference does not make them any less professional, however.

\section{PUBLIC SERVICE VALUES IN LOCAL GOVERNMENT MANAGEMENT}

Expertise in local government management is the necessary condition for a professional city or county manager, but it is not sufficient. The professional in public service must also have appropriate values which guide him or her in using that expertise for the benefit of the community. Values of personal integrity and of service to one's clients are common to many professions and are no less important for local public managers. Other values, however, are more specific to the work of city and county management, our focus here. (We expect that these three public service values may also be central to other public service professions, although we have examined only city/county managers.) We identify the three key values as respect for other professionals' expertise, recognition of the legitimacy of politics and the authority of elected officials, and acceptance of an ethic of responsibility to the public at large.

What are the sources of these values, and how do they come to shape city/county managers' behavior? These values are internalized by many managers through professional education, through professional associations, and through the political and organizational system in which they operate.

Discussions of these values are usually part of the MPA education of local managers. Although they may not be explicitly the subject of a particular course, they typically inform the teaching of various subjects in the MPA curriculum. They are also widely discussed in training sessions offered by various government and professional organizations.

Each of these values is also incorporated in the ICMA Code of Ethics and/or the ICMA Declaration of Ideals. All ICMA members agree to the ICMA Code of Ethics--a more specific guide than that of many professional groups. Members are given guidance in applying the Code and understanding the Ideals of the ICMA through professional meetings, the monthly magazine Public Management, and other publications. The ICMA is empowered to hear complaints against members, to investigate, to censure violators, to publish a list of censured members, and to expel wrongdoers.

\section{Respect for Other Professionals' Expertise}

City and county managers depend on other professionals to accomplish much of their work. They need to respect others' expertise if their own judgments are to be sound and the work of local government is to be done well. Indeed, with the complexity and size of many organizations, the expanding political and policy role of 
managers, and the increasingly technical work of local government, managers cannot be very involved in the day-to-day operations of the departments. Obviously, extensive delegation to other professional administrators - whether assistant managers or department heads -- must be expected, especially in larger cities and counties.

The professional judgments of attorneys, fire chiefs, police chiefs, engineers, parks directors, planning directors and other experts in line services are also valuable to the manager. As Romzek and Dubnick point out in their analysis of the Challenger space shuttle explosion, general managers who substitute bureaucratic control for deference to professional judgment run the risk of incurring great losses.(17)

The city or county attorney is one professional whose advice can be critically important to the manager. In their study of city managers and city attorneys, Buckwalter and Legler conclude: "Interviews and the survey results repeatedly emphasize that success of the city manager-city attorney relationship is contingent on achieving a high level of mutual respect, both personal and professional. "(18)

The ICMA Declaration of Ideals does not dwell on this value, but does include it under two headings. ICMA members are to:

7. Develop a responsive, dynamic local government organization that continuously assesses its purpose and seeks the most effective techniques and technologies for serving the community.

8. ...create an environment that inspires excellence in management and fosters the professional and personal development of all employees.(19)

This value also implies that city and county managers act as role models for other professionals in local government. By their own behavior, managers should set the tone of professionalism in their organizations and demand similar professionalism of their subordinates. Supporting professional development activities, such as tuition reimbursement and travel to professional conferences, is also part of the manager's responsibility toward other professionals. By encouraging, recognizing, and rewarding the development of expertise and accountability by others, managers develop organizations that are responsive, dynamic, and effective.

However, the manager's role in encouraging other professionals in local government is not without difficulty. Professional training, socialization, and perspectives may vary a great deal from one profession to another, and may at times put the city or county manager at odds with department heads or whole groups of professionals. Frequent are the anecdotes about the unique culture and values of police and fire departments, planners, and engineers. Buckwalter and Legler found: "Most manager- attorney relationship patterns are characterized by a certain aloofness and independence."(20) Other professional groups within local government may seek to insulate themselves from both hierarchical controls and input from the community to allow themselves greater discretion over policy development and implementation. Probably one of the greatest managerial challenges for city and county managers occurs when department heads or other government professionals work not so much at serving the public as at building bureaucratic fiefdoms in alliance with outside groups.

Even those who do not knowingly promote fragmentation within the local government also face conflict among competing values in much the same way that managers do. Whether they are police officers, planners, attorneys, social workers, or engineers, they develop expertise and commitment to their own professions, but must be sensitive to the value of other professionals, the political authority of the board, the executive authority of the city or county manager, and the legitimacy of citizen input.

In addition, the manager must often make difficult choices that balance the expert advice of professionals with the community's needs and demands. Sometimes other professionals may not be as attuned to the political environment or the authority of the elected board as the manager must be. Sometimes their professional counsel needs to be heeded if the board is to avoid a serious mistake. The manager must have the courage to support and 
promote the professional advice of others in the organization when he or she believes that it is in the best interest of the community. And when other values must prevail over professional expertise, the manager should be able to clearly communicate the reasons for such a decision.

\section{The Legitimacy of Politics and the Authority of Elected Officials}

In the council-manager form of government, managers serve only as long they have the support of a majority of the elected board. Thus, as Hansell suggests, this system creates a structure for professional accountability more similar to the fusion of powers in the British parliamentary system than to the division of powers found in American state and federal governments or in executive mayor local governments.(21) Managers must be professionally expert, but they must also have political savvy to withstand criticism and rise above the political and policy conflicts. However, managers and councils may disagree over the appropriate policy role for the chief executive. $(22)(23)(24)$

Recognizing the authority of elected officials does not mean that local government managers should meekly follow the governing board's orders, regardless of what the board asks. In the first place, managers should resist illegal and unethical acts and orders. Moreover, the manager needs to use his or her professional expertise to advise the board on policy matters. Yet managers need to recognize that their professional advice must give way to the decisions of the legislative body. A professional manager does not seek to undermine the council or engage in subsequent delays in implementation. Recognizing that policy decisions will often be based upon political factors, managers must understand that conflict and factionalism on the board often represent legitimate political divisions within the community. If managers are unable to reconcile this fact with their professional role, they are sure to have a short career or suffer countless hours of torment.

The role of the city or county manager in policy development and external political relations has long been problematic for the profession. Early reformers' conceptions of the manager's role in policy were limited to advice and policy execution, thus idealizing the dichotomy between politics and administration.(25)(26) In practice, however, managers have long been involved in all aspects of the policy process and are also profoundly affected by the interplay of politics in administration. Community power studies, accounts by managers themselves('), and surveys or interviews with various city officials(29)(30)(31) have emphasized that managers cannot, do not, and should not insulate themselves from policy conflicts. Yet, as Svara indicates, many managers are still not completely comfortable with the mixing of policy and management responsibilities.(32)

As a guide to managers, the ICMA has updated its Code to reflect the realities of the manager's policy role:

1. Be dedicated to the concepts of effective and democratic local government by responsible elected officials and believe that professional general management is essential to the achievement of this objective....

5. Submit policy proposals to elected officials; provide them with facts and advice on matters of policy as a basis for making decisions and setting community goals; and uphold and implement municipal policies adopted by elected officials.

6. Recognize that elected representatives of the people are entitled to the credit for the establishment of municipal policies; responsibility for policy execution rests with the members [of the ICMA].

7. Refrain from participation in the election of the members of the employing legislative body, and from all partisan political activities which would impair performance as a professional administrator.(33) 
Although elected officials hire and can remove managers from public office, the city or county manager ultimately is responsible to the citizens of the community, not just to the governing board. This responsibility entails not only seeing the public as his or her ultimate employer, but also maintaining the interests of the community as an overarching goal. In many, perhaps most, localities in the United States today a variety of publics clamor for government attention. Serving the various publics' differing needs, promoting processes that encourage meaningful citizen participation, and seeking to guarantee what has been called "regime values" are all part of this public service ethic. The ICMA Code of Ethics clearly states that the manager must:

4. Recognize that the chief function of local government at all times is to serve the best interests of all of the people.(34)

This value of a public service ethic is not new, although certainly an emphasis upon citizenship, citizen participation, and civicism in the literature of public administration has seen a healthy renewal in the last decade. (See, for example,(35) (36)(37)(38)) Indeed, the early reformers who advocated the adoption of the council-manager plan emphasized that it promoted the public interest. Critics have argued that "public interest" was often narrowly defined as middle class interest in economy, efficiency, and economic development.(39) More recently, those associated with the New Public Administration movement sought to encourage public administrators to empower disadvantaged citizens, to encourage effective citizen participation, and to promote social equity.(40) The ICMA Ideals now reflect the view of public responsibility propounded by Terry Cooper:

An understanding of professionalism in public administration which is appropriate for a democratic society should be one which is grounded (sic) in what is... a high ethical view of citizenship. We should identify ourselves first with the citizenry in their sharing of authority and their right and obligation to participate in the affairs of the political community.... We should not do it for the selfserving instrumental reasons which are so typical of "professional" activities in many fields.(41)

Nowhere is this identifIcation with the citizenry so obviously necessary as in local government, which traditionally has been the most accessible level of government. The ICMA Ideals stress that managers:

1. Provide an environment that ensures the continued existence and effectiveness of representative local government and promotes the understanding that democracy confers privileges and responsibilities on each citizen.

2. Recognize the right of citizens to influence decisions that affect their well-being; advocate a forum for meaningful citizen participation and expression in the political process; and facilitate the clarification of community values and goals.(42)

Identifying with these ideals and applying them to actual practice is not as straight-forward as it may seem. Because local government is more accessible to citizens, and because many local matters directly affect citizens' daily lives, local government managers are often quite directly involved in the competing definitions of the public interest which reflect the positions of various people in a single jurisdiction.

As they develop technical expertise and professional standing, public administrators at all levels may be tempted to dismiss theviews and rights of citizens who are less expert than they. (And in city hall, many citizens may seek to participate or ask for assistance where they never would elsewhere in government.) It is also difficult to maintain one's professional composure and commitment to public input when verbally attacked by angry citizens. In addition, public officials may find it easier to view citizens merely as consumers of public services than as participants in the process of government. Public input slows the decisionmaking process after all, and many issues of importance can become mired down in lengthy debate when the citizens have a direct interest in them. 
Understanding the needs and concerns of a community may be particularly difficult for managers who are hired from outside the jurisdiction, as is typically the case. Outsiders must make an extra effort to learn about the entire community -- not only from the viewpoint of the council members, the business elite, or other government officials, but also from the perspective of the disadvantaged, the powerless, and minority groups. Not only is this difficult because of their newcomer status and their more frequent interaction with elites, but it is also a problem because of the social background of most city and county managers. Most managers are still white, middle-class males.(43) We recently found a striking example of a manager's failure to understand and appreciate the unique character of the community. In our telephone interview a former manager expressed disdain for the large Haitian population in the city where he had been manager.(44) Evidence of his unwillingness to interact with these citizens was clear in the fact that he refused to live in the community, but chose to commute a long distance and retain his family residence in another city.

Understanding the community obviously is a problem faced by other experts in local government who frequently are hired as "outsiders" to offer a fresh point of view or particular expertise--e.g., school superintendents, city attorneys, police chiefs. The ICMA Declaration of Ideals clearly addresses this challenge of public service professionalism by encouraging managers to:

3. Respect the special character and individuality of each community while recognizing the interdependence of communities and promoting coordination and cooperation....

6. Advocate equitable regulation and service delivery, recognizing that needs and expectations for public services may vary throughout the community.(45)

\section{ACHIEVING PROFESSIONALISM IN LOCAL GOVERNMENT}

As we have seen, city/county managers can be public service professionals. Those who are not only have expertise, but also embody public service values. These values may quite naturally conflict with one another on occasion. At times, a manager must implement the decisions of the elected legislative body when the manager prefers another choice--perhaps one promoted by other professionals in the government or by the community at large or by the manager's expert understanding of what should be done. This brings us full circle to our starting point--i.e., the tension between the need for expertise and the need for popular accountability. Local government professionals must frequently grapple with particular cases and circumstances that require them to make trade-offs and to resolve dilemmas of expertise and accountability. Ethical choices are often difficult, and professionalism provides no simple answers. What the profession does provide is an appreciation of these choices as ethical choices, a set of statements about what values are important, and a group of professional colleagues who can be consulted for advice.

The three critical professional public-service values we have discussed in this paper--respect for other professionals' expertise, recognition of the legitimacy of politics and the authority of elected officials, and acceptance of responsibility to the community at large--are not automatically part of the manager's mindset. Being a city or county manager is no guarantee of subscribing to these ideals, since entry to the practice is controlled by elected officials. Some individuals will be hired who have little interest in or exposure to upholding these values. Managers must learn these values through professional education, professional association contacts, and work with other professionals in local government.

Perhaps just as importantly, for these values to work well, the local governing board must also accept them and apply them in their interactions with employees, citizens, and the manager. The problem in developing local government professionalism often lies in the failure of the legislative body to respect the professional judgement and expertise of its professional employees. As our research on city manager turnover in Florida cities indicated, elected officials' unwillingness to respect the expertise or professional values of the city manager can force a standoff between council and manager which can be broken either by a vote to remove the manager or by the manager's resignation.(46) In more than one case in Florida, a manager left office after he 
refused to acquiesce to an illegal act the council wanted him to undertake. In other cases, council members had their own agendas and were not interested in the managers' advice or information. Council members in some places removed competent and professional managers from office because they disagreed with the manager's role or simply because a new political faction took office.

The issue of turnover in office suggests yet another barrier to professionalism in local government administration - the permanent loss of qualified managers to the profession. Some experienced managers exit the profession entirely.(47) Some leave for positions in private business, because they are more lucrative or outside the glare of press scrutiny. Others leave city management out of frustration with the political conflicts they face. Still others leave because they do not feel equipped to deal constantly with the tensions between using their professional expertise, complying with the wishes of the council, and serving the public. Thus, many who enter city and county management with high hopes and a commitment to public service do not develop a life-long career in the profession.

Despite these difficulties in achieving professionalism in local government, many managers do successfully use their expertise in the context of the three public service values we have discussed. They develop methods of conflict management that work well in their particular cities and counties. Many managers believe in and exemplify the ICMA Ideals and Code of Ethics. Their professionalism and that of their colleagues makes many local governments more effective, efficient, responsible, and equitable. They combine expertise with popular accountability as local government professionals.

City and county managers are a visible and important group of professionals in local government. Their lack of autonomy in carrying out their work does not mean they are less professional than private sector professionals. Rather, their accountability to the public and to elected officials exemplifies the distinguishing characteristic of public service professionalism: commitment to public service values.

\section{REFERENCES}

1. Pugh, Darrell L."Professionalism in Public Administration: Problems, Perspectives, and the Role of ASPA." Public Administration Review 49 (January/February 1989): 1-8.

2. Ibid.

3. Nalbandian, John "Tenets of Contemporary Professional in Local Government." Public Administration Review 50 (November/December 1990): 654-662.

4. Stillman, Richard J. II. The Rise of the City Manager: A Public Professional in Local Government, University of New Mexico Press, Albuquerque, 1974.

5. Green, Roy E. The Profession of Local Government Management: Management Expertise and the American Community, Praeger, New York, 1989.

6. Stillman, op cit.

7. Green, op cit.

8. Ibid.

9. Kirchhoff, Bill "Babbitt Could Have Been a Manager." Public Management 72 (September 1990): 2-6.

10. ICMA/NASPAA Joint Task Force on Local Government Education. Guidelines on Local Government Management.

11. Green, op cit.

12. Local governing boards also exert a major influence on the make-up of the managers' professional association. Until 1987, eligibility for full membership in ICMA was, in fact, controlled by local governing boards. Only those who had served a designated period as chief administrator of a local government could become full members of ICMA. Managers have now established another route to full membership, however. Since 1987, assistants who are appointed by the chief administrator and have served three years are eligible to become full members. Thus, it is now possible to gain full entry into the professional association on the basis of approval (i.e., hiring and retention) by another ICMA member. But membership in the association is neither a prerequisite to nor a guarantee of opportunity to serve as a city or county manager. 
13. Barber, Daniel M. "Newly Promoted City Managers." Public Administration Review 48 (May/June 1988): 694699.

14. Ammons, David N., and Glass, James J. "Headhunters in Local Government: Use of Executive Search Firms in Managerial Section." Public Administration Review 48 (May/June 1988): 687-693.

15. DeHoog, Ruth H., and Whitaker, Gordon P. "Political Conflict or Professional Advancement: Alternative Explanations of City Manager Turnover." Journal of Urban Affairs 12 (1990): 361-378.

16. Whitaker, Gordon P., and DeHoog, Ruth Hoogland "City Managers Under Fire: How Conflict Leads to Turnover." Public Administration Review 51 (March/April 1991): 156-165.

17. Romzek, Barbara S., and Dubnick, Melvin L. "Accountability in the Public Sector: Lessons from the Challenger Tragedy." Public Administration Review 47 (May/June 1987): 227-238.

18. Buckwalter, Doyle W., and Legler, J. Ivan. "City Managers and City Attorneys: Associates or Adversaries?" Public Administration Review 47 (September/October 1987): 393-403.

19. International City Management Association Who's Who in Local Government Management, ICMA, Washington, DC, 1990.

20. Buckwalter and Legler, op cit.

21. Hansell, Bill "The Missing Ingredient: A Credible Civic Infrastructure." Public Management 70 (December 1988): 4-5.

22. Nalbandian, op cit.

23. Svara, James H. Official Leadership in the City: Patterns of Conflict and Cooperation, Oxford University Press, New York, 1990.

24. Whitaker and DeHoog, op cit.

25. Childs, Richard S. The Hirst 50 Years of the Council-Manager Plan of Municipal Government, National Municipal League, New York, 1965.

26. East, John Porter. Council-Manager Government: The Political Thought of Its Founder, Richard S. Childs, University of North Carolina Press, Chapel Hill, 1965.

27. Kammerer, Gladys M., Fan-is, Charles M., DeGrove, John M., and Clubok, Alfred B. City Managers in Politics: An Analysis of Manager Tenure and Termination, University of Florida Press, Gainesville, 1962.

28. Harlow, LeRoy F. (ed.). Servants of All: Professional Management of City Government, Brigham Young University Press, Provo, 1981.

29. Loveridge, Ronald O. City Managers in Legislative Politics, Bobbs-Merrill, Indianapolis, 1971.

30. Newell, Charldean, and Ammons, David N. "Role Emphases of City Managers and Other Municipal Executives." Public Administrative Review 47 (May/June 1987): 246-253.

31. Svara, op cit.

32. Svara, James H. "Dichotomy and Duality: Reconceptualizing the Relationship Between Policy and Administration in Council-Manager Cities." Public Administration Review 45 (January/February 1985): 221232.

33. International City Management Association, op cit.

34. Ibid.

35. Cooper, Terry "Citizenship and Professionalism in Public Administration." Public Administration Review 44 (Special issue, March 1984): 143-149.

36. Frederickson, George H. "The Recovery of Civism in Public Administration." Public Administration Review 42 (November/December 1982): 501-508.

37. Frederickson, George H., and Hart, David K. "The Public Service and the Patriotism of Benevolence." Public Administration Review 45 (September/October 1985): 547-554.

38. Gawthrop, Louis C. "Civis, Civitas, and Civilitas: A New Focus for the Year 2000." Public Administration Review 44 (Special issue March 1984): 101-106.

39. Hays, Samuel P. "The Politics of Reform in Municipal Government in the Progressive Era." Pacific Northwest Quarterly 55 (1964): 157-169.

40. Frederickson, George H. New Public Administration, University of Alabama Press, University, Alabama, 1980.

41. Cooper, op cit. 
42. International City Management Association, op cit.

43. Green, op cit.

44. Whitaker and DeHoog, op cit.

45. International City Management Association, op cit.

46. Whitaker and DeHoog, op cit.

47. Ibid. 